\title{
Sedimentology Studies and Environmental Impacts of Land Subsidence in Eslamshahr, SW Tehran, Iran
}

\author{
Khalil Rezaei \\ Assistant professor, Sedimentology, Geology Department, Kharazmi University, Tehran, Iran. \\ Khalil.rezaei@khu.ac.ir
}

\begin{abstract}
It was recognized that a large area in Tehran plain, especially in southwest of Tehran (North of Iran), is subject to the land subsidence. Two major zones of subsidence have been identified and one of these zones has been monitored for several years by leveling. Land subsidence can be caused by a variety of processes, but most land subsidence in Iran is associated with aquifer compaction caused pressure decline associated with groundwater withdrawal. This study aims at zoning land subsidence and recognition of geometrical factors in southwest of Tehran. To estimate and predict land subsidence, all the effective subsidence factors were identified. Among the factors, nine most important factors including, downfall of groundwater, thickness of clay, depth of groundwater, annual discharge of water from wells, the distance of well to each other, slop, elevation, land use and geology were evaluated. In this study, we collected and correlated 40 geotechnical boreholes in Eslamshahr city and around it and then prepared soil type distribution maps for several depths. Finally, these maps overlaid with water table and land subsidence maps. On this study also, the Landsat and Spot Satellites data together with the ArcGIS, Surfer and Excel have been applied in order to analyze the data and prepare the maps and diagrams. Furthermore, field surveys and study and number of geomorphic features have been involved in the study. In basin-fill aquifers, like Eslamshahr, most of the aquifer compaction is due to the dewatering and compression of fine-grained sediments. Once the fine-grained units begin to compress and lose porosity, compaction becomes permanent, overall water storage in the basin fill is reduced, and land subsidence occurs. In sedimentary basins, groundwater in unconsolidated aquifers is pumped from the pore spaces between sand and gravel grains, causing a lowering of pore-water pressure. The decrease in pore pressure results in an increase in the effective stress in the high-permeability low-compressibility coarse-grained aquifers and timedependent pore-pressure reduction in the low-permeability high-compressibility fine-grained aquitards, and this increase in effective stress is equal to the decrease in fluid pressure. Because fluid pressure within the pores of a granular matrix helps support overlying aquifer material, a reduction in pore-water pressure causes an increase in overburden stress (weight) to the aquifer matrix, causing the aquifer matrix to change volume (compact). Land subsidence may result in various types of land-surface movements that can potentially cause problems if human development exists within the subsiding area. High subsidence rate in urban areas increases the risk of ground opening and collapses, flooding and damages of their infrastructures due to the induced surface fracturing by subsidence.
\end{abstract}

Keywords: Land Subsidence, Sediment, Groundwater, environmental impacts, Eslamshahr.

\section{Introduction}

Study of natural hazards such as land subsidence in urban areas is of great importance. The destruction of bridges, roads, structures and municipal facilities and etc., are some of the damages which are caused by land 
subsidence (Poland and Davis, 1969; Amighpey et al., 2006; Mahmoudpour et al., 2013; Motagh, et al., 2007, 2008; Bell et al., 2002; Ortiz-Zamora, et al., 2010). The consensus among experts and environment officials is that Tehran, capital of Iran and around it is losing the battle against land subsidence. This area is facing a new crisis as for the last four months seven streets in different districts of the city have collapsed. The collapses in Tehran might have been triggered by various reasons such as gas explosion, subway tunnel excavation or water pipe breaks but ultimately they are resulted from depleting ground water resources (Fig.1). One of the major causes of this problem is human negligence and their insufficient knowledge in groundwater extraction (Shemshaki, 2005; Mosavi, 2003; Motiee, et al., 2006). By developing of agriculture and reducing surface water, people tried to seek ways to exploit underground water, without sufficient attention to the manner of the revitalization of these reservoirs (Zektser and Lorne, 2004; Peduzzi, 2009; Chaussard et al.,2014; Dixon et al., 2006; Ghorbanbeigi et al., 2008). Southwest of Tehran include Eslamshahr area has low land slope up to quite smooth with fine sediment and impermeable texture. Increased construction and population expansion and also excessive removal of underground water supplies, resulted lowering the water level and consequently led to land subsidence in this area (Hu et al., 2004; Teatini et al., 2006). Wei (2006) confirmed that the reduction of exploitation of groundwater is the only way to stop land subsidence. Morseli (2008) in his thesis investigated the land subsidence due to groundwater levels drop in the plains of Varamin and south of Tehran. Given the above background, the purpose of this research is sedimentary mapping of land subsidence and its environmental impacts in Eslamshahr area. In this study, we have used geotechnical and hydrological data for site effect investigations during land subsidence.

\section{Study Area}

The study area is located in southwestern city of Tehran-Iran (Fig. 2). This area is faced with the problem of subsidence. Southwest of Tehran includes residential areas, too many farmlands and different industrial areas with semi-arid climate. During 1991 to 2004, too many elevation impressions were made from different parts of southwest of Tehran. It is defined that these part of lands were experiencing subsidence during that period of time. Southwest of Tehran is located at the end of Tehran's plain. Among the prominent features of this area, it can be pointed out that the flat and low slope and sedimentary soil quality of large part of this area especially towards the south of region (Fine alluvial deposits) and also excessive harvesting of groundwater, land subsidence is considered one of the issues and crisis of these lands. Geologically, Alborz Mountains in north of area, were formed from a processes of faulting and mountains movements due to Arabic Plate movement (towards $\mathrm{N}$ of Iran) and collapsing with Eurasian Plate. Therefore, the layers in the area and their structures were not uniform (except in Eocene Era), where Hezar Derahe formations were formed in Tehran-Karaj area. Hezar Derahe formations are divided into Hezar Derahe alluvial (sediment A), inhomogeneous alluvial sediment of $\mathrm{N}$ Tehran (Bn), where it is silt in Kahrizak sediment (Bs) and in Tehran alluvial (sediment C)(GSI, 2008; 2008; 2007; 2005).

\section{Methodology}

In this study, in order to evaluate and estimate the amount of subsidence, 9 variables including: drop in groundwater, thickness of clay, land use, geology, groundwater depth elevation, slope and wells relative distance to each other and the annual discharge of water from wells were used. For this purpose, the required maps for each of the criteria were developed in GIS environment. Data required for mapping criteria was received from various sources such as; library, field work, as well as information obtained from the National Geology organization and finally the required output map were extracted in Arc GIS software. SPSS software was used for statistical analysis. After preparation of subsurface maps, we overlay location of collapses on these maps make correlation results between sedimentary columns, water table and collapses.

\section{Discussion}

In comparison to the rate of groundwater-induced deformation in other well-known basins such as Las Vegas, USA (Bell et al., 2002), Mexico City, Mexico (Poland and Davis, 1969) and New Orleans, USA (Dixon et al., 2006), Iran currently hosts some of the fastest sinking valleys and plain aquifers in the world. Hence, unregulated groundwater extraction and the associated subsidence in the future may also threaten non- 
agricultural regions, resulting in costly damage to infrastructure due to changing ground levels. While damage to infrastructure can be repaired, the impact of depleted groundwater supplies will be more insidious, with immense social, economic and environmental consequences. Future climate change is expected to put additional stress on ground water resources in Iran (Mousavi, et al., 2001; Morseli, 2008; Sarraf, 2005).

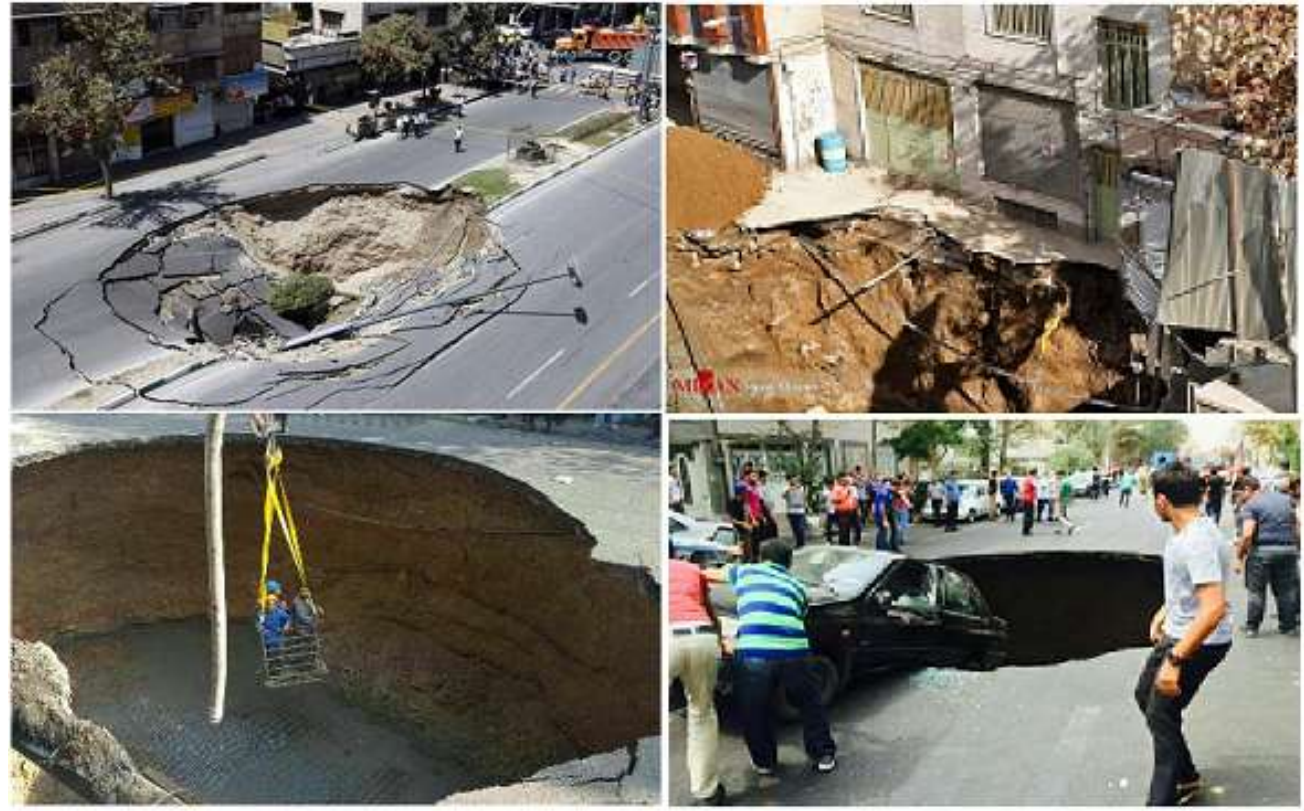

Fig. 1: Pictures from Land Subsidence in Study Area, Eslamshahr, SW Tehran.

Land subsidence phenomenon is related with several factors include; groundwater depletion, soil and sedimentary column, land use, subsurface structures and so on. The increased demand for groundwater and the high rate of subsidence resulting from overexploitation of this valuable resource are likely to become a serious challenge for future development at groundwater basins of central and northeast Iran. The area surrounding Tehran with a population of about 14 million people is subject to groundwater-induced deformation (Fig.1).

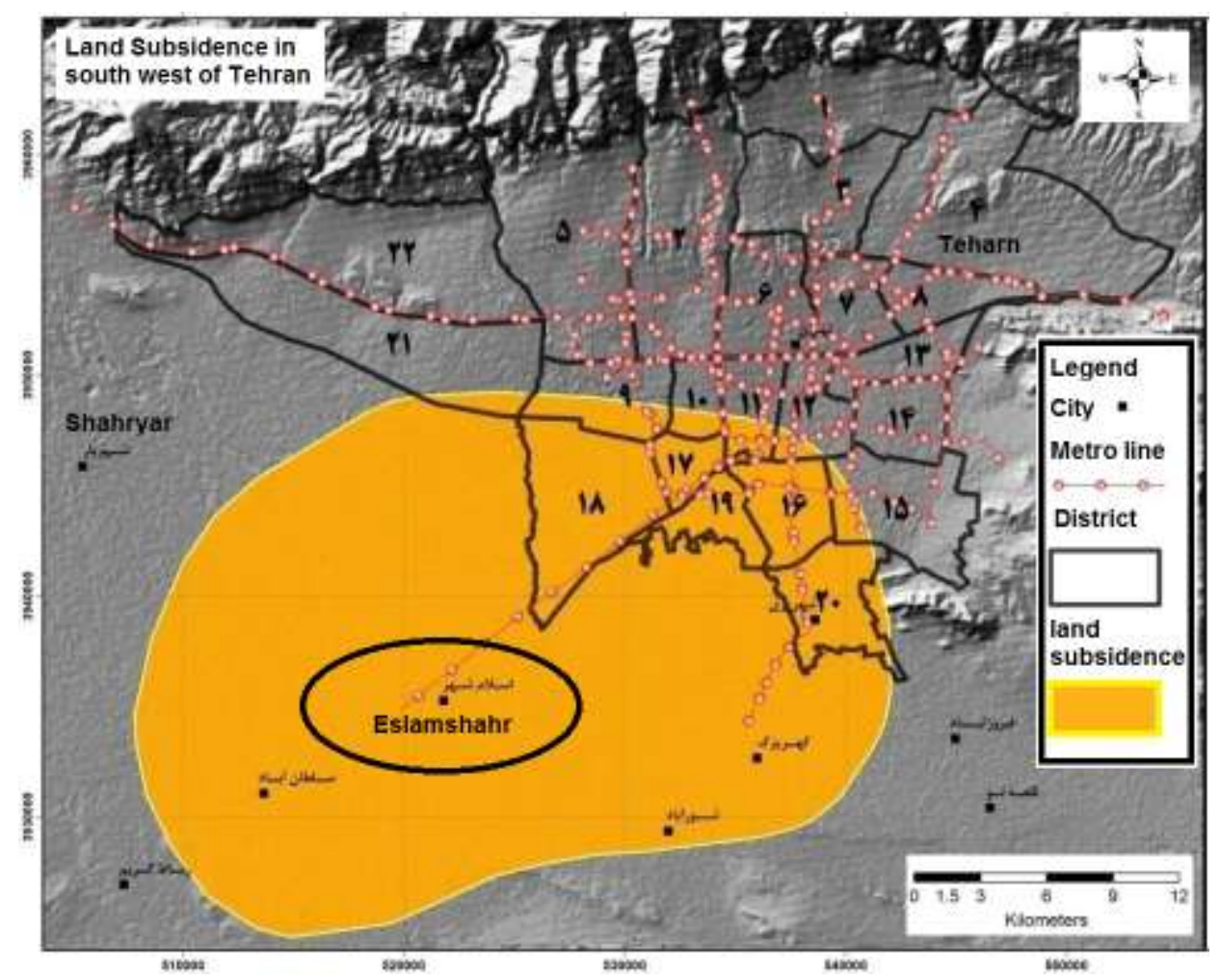

Fig. 2: Map of land Subsidence District in SW Tehran. 


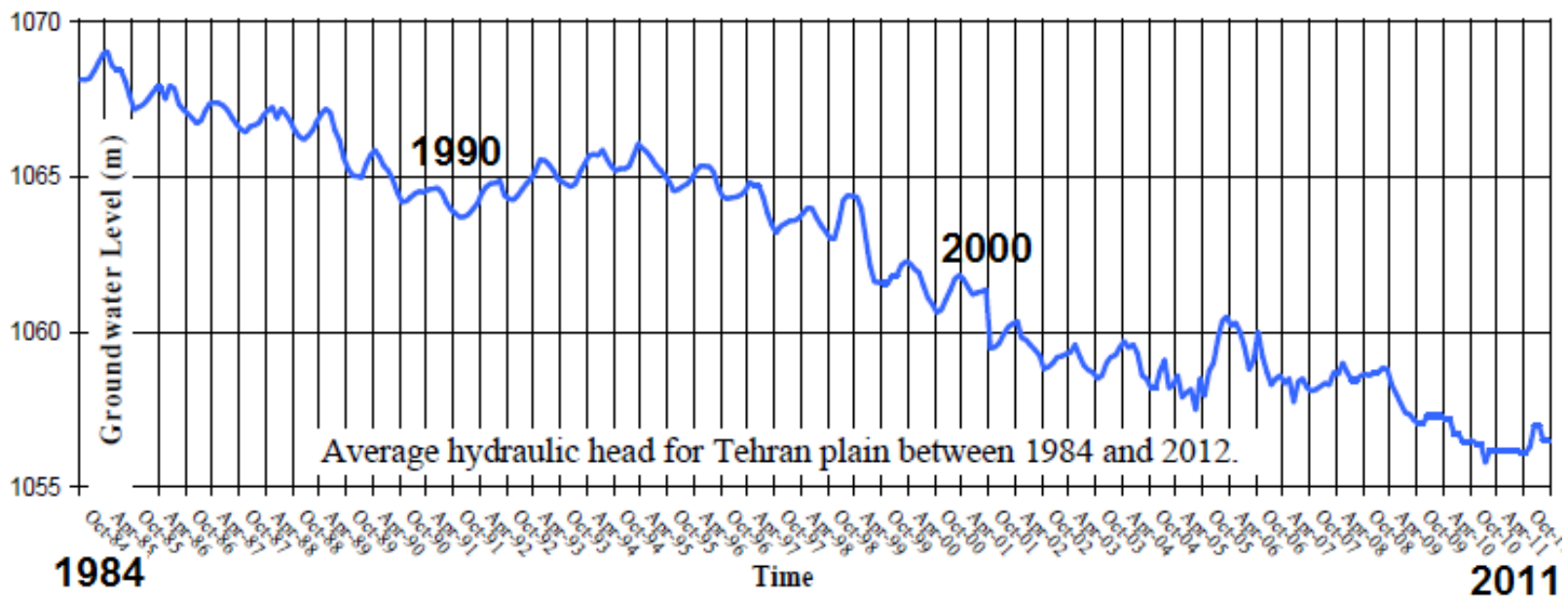

Fig. 3: Groundwater Head Changes during time in Study Area.
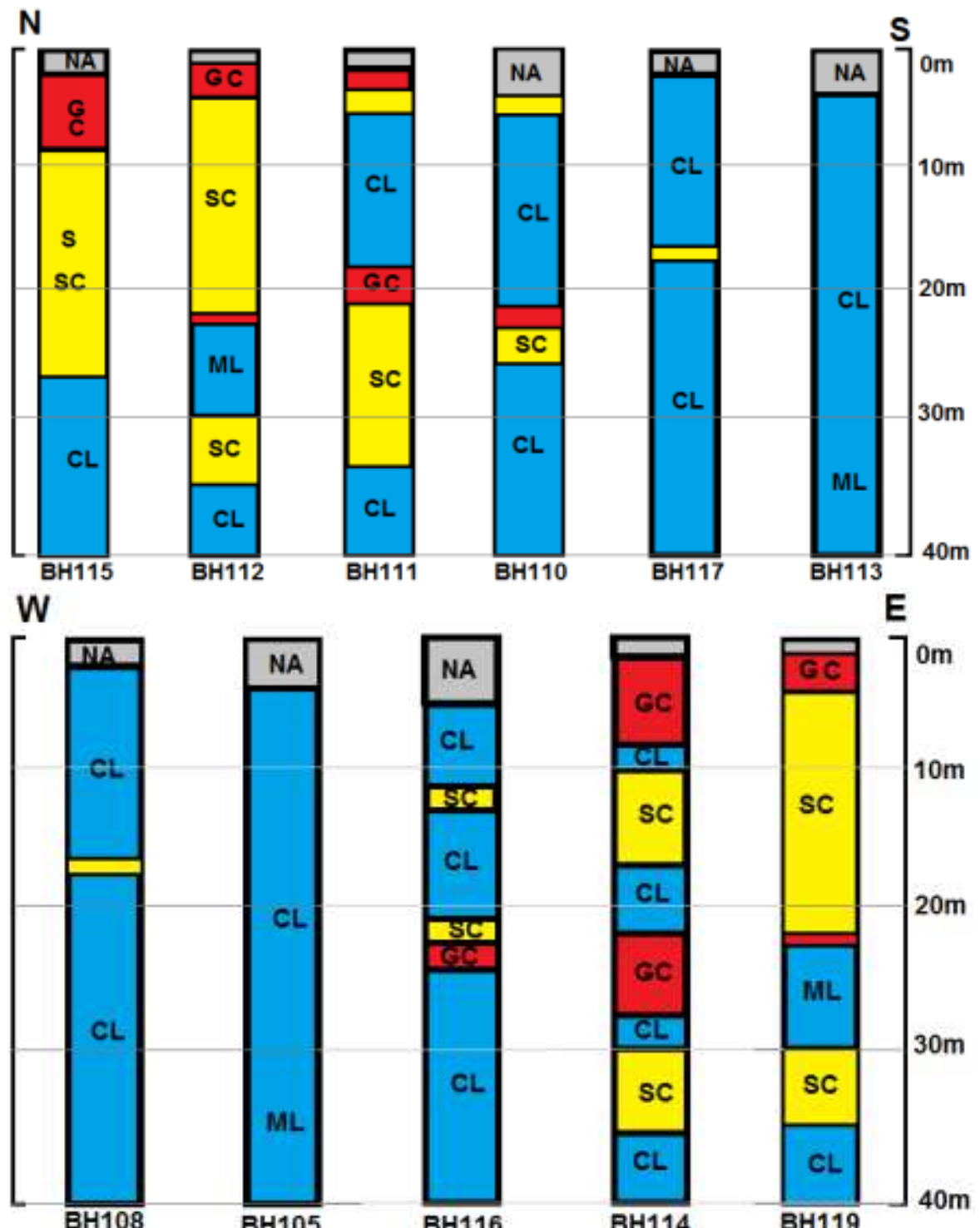

Fig. 4: Grain Size Changes in two NS and WE Directions in Boreholes Through Eslamshahr City. 
Tehran's groundwater supply have been depleted over the past decades, partly due to uncontrolled immigration and rapid population growth, and partly due to increased extraction, for industry and farming activities spreading across the area (Sarraf et al., 2005). Since the 1990's, extensive overexploitation of groundwater is evidenced by a fall of 13 to $19 \mathrm{~m}$ in groundwater level in this area (Fig.3). Official estimates claim that there are currently 8000 illegally drilled wells in the Tehran province, while the unofficial estimates put this figure closer to 30,000 (http://iran-daily.com/1384/2384/html/panorama.htm\#s93396). The satellite data shows surface deformation in Tehran mainly occurs in two regions: one in the western part of the Tehran Plain and one in the Varamin area to the southeast of the Tehran Plain (Figure 1a). The subsidence feature in Western Tehran exhibits as much as 14-18 cm of subsidence for the 140-day time interval between 13 June and 31 October 2004, which is $36 \mathrm{~cm} / \mathrm{yr}$ assuming a constant rate (NCC, 2007; Motiee et al., 2006; Pishro , 2016). In some locations of Eslamshahr area, it relies heavily on groundwater supplies, which are delivered by tunnels (known regionally as Qanat) for irrigation and industrial needs. Groundwater level measurements for several piezometric wells show a steady decline of about $18 \mathrm{~m}$ since the 1970's.

In previous investigations, comparing InSAR-derived subsidence maps and Landsat TM images reveals that subsidence mainly affects agricultural settings (auxiliary1 KML Google Earth files), demonstrating that groundwater pumping for agricultural activities is the major responsible for land. Piezometric data show some seasonal fluctuations that are expected to have some influence on the subsidence rate (Schmidt and Burgmann, 2003; Burgmann et al., 2000; Martínez et al., 2015). Careful monitoring of groundwater resources is therefore necessary and caution should be taken to properly use groundwater so as to reduce the socio-economic consequences of overexploitation that might be felt across national boundaries. Finally, we point out the importance of acquiring detailed hydrological data such as well locations, exploitation rates and lithostratigraphic maps of subsurface sequence in areas affected by land subsidence to better understand the relation between surface displacements and the lowering of the groundwater level. Such information, coupled with continued monitoring using Remote Sensing, has the potential of revealing further details of the hydrology of the areas of subsidence and the geo-mechanical parameters of the underlying aquifer structure. In some of areas water well casing seems to rise into the air or showing to be sticking out of the land surface or sometimes produces fissures in the soils and/ or showing as sinkhole in carbonated rocks that damage canals, water networks, gas pipelines, oil pipelines and dams(Fig.).

Topography of the area is also changed that affected flood regime and water recharging into ground aquifers. This phenomenon becomes distinct physically and sometimes dramatically visible. From Water resources point of view and Surface waters, there are 7 seasonal rivers and only 2 permanent rivers, namely Khan and Karaj, from which the required water is maintained for the valleys. In the past years, part of Tehran's water is maintained from ground water from 522 canals. Drilling a big number of wells in the two valleys caused most of the canals to go dry once ground water level went down.

About Ground water and Aquifers, There are actually 3 alluvial aquifers in Tehran - Shahryar valleys (Fig.4).The aquifers in Tehran-Shahryar valleys are divided into 3 aquifers namely: 1) Northern aquifer: It is extended from Elburz Mountains down to Abasabad-Yusifabad of Sediment A with a little permeability, the water of which flows into the main aquifer. 2) Main aquifer: It is extended from Lavizan hills down to BibiShahrbano, west (Shahrake-gharb) and Karaj aquifer and eastward to Shahrake-Hashtgerd fault. The sediments of the aquifer are $\mathrm{C}$ and $\mathrm{B}$ (with an average thickness of 130 meter and decreasing towards $\mathrm{S}$ and $\mathrm{E}$ ) with medium to high permeability. The aquifer layers inclined at 50 per 1000 at $\mathrm{N}$ and NW while it is less than one per 1000 at middle of the aquifer. Water flows mostly from N to S (and NW to SE in the west part of the aquifer). Water recharge into aquifer consists of floods, permanent rivers, seasonal rivers, waste water and agriculture water. Transmissibility factor of the aquifer is variable between $50 \mathrm{~m}^{2} / \mathrm{d}$ in NE, $2000 \mathrm{~m}^{2} / \mathrm{d}$ in W (Shahryar valley) and $2000 \mathrm{~m}^{2} / \mathrm{d}$ at the middle of the aquifer. Moreover, the average storage factor varies from 1 to 3 percent (less at $\mathrm{S}$ and more at NE (15\%). 3) perched aquifers: They consist of separated small aquifers in separated thin sediments of A and B.

Geology and Geophysics of the aquifers show that Elburz Mountains are an old Paleocene-Eocene rock with a medium permeability that recharges the aquifers and surrender it from $\mathrm{N}$. The aquifers sediments are made of above mentioned sediments (i.e. mainly quartz toward $\mathrm{S}$ with a high permeability) which came from weathering process of the mountains. The geophysics of the area was carried by CGG of France by using about 300 electrical soundings (mostly with $A B=2000 \mathrm{~m}$ ). Electrical resistivity of new sediments is $300 \Omega \mathrm{m}$ and decreasing towards $\mathrm{S}$, while the old sediments have a resistivity of $25 \Omega \mathrm{m}$. This study indicates that the aquifer 
thickness is mostly in $\mathrm{N}(400 \mathrm{~m})$ and $\mathrm{NW}(300 \mathrm{~m})$ (as a syncline basin) that changes to $25 \mathrm{~m}$ in $\mathrm{E}$, SE and SW due to uplift in basement rock. Aquifer's water level changes. The average annual water level drop in the main aquifer is about $40 \mathrm{~cm}$ as computed from the unit hydrograph. Overlaying of subsurface sediments and collapses occurrence show that there is nearly good correlation between maximum water table depletion, loose sediments, clay thickness (Fig. ). When water is removed from the ground, the pore water pressure (the pressure of groundwater held in gaps in soil) is reduced. In other words, the lack of water means there is nothing holding up the weight of the soil above it, resulting in land surface subsidence.

For solution, some aquifer systems can "rebound" if water is pumped back into them and groundwater resources are allowed to recharge, it rarely happens. However, checking the progress of land subsidence is not only possible but attainable, provided officials and ordinary people cooperate. Collapses are the inevitable outcomes of ignoring environmental factors. Urban development and building boom has turned the aquifers into hallow whole which may collapse at any time. Another issue is soil liquefaction (where soil substantially loses strength and stiffness causing it to behave like a liquid). Also, Tehran's old water supply network can intensify any imminent collapse. Lack of coherence in urban management eventually results in a city which is not safe from disasters.

\section{Conclusions}

Subsidence is an environmental phenomenon that involves gradual or sudden settlement of the land surface because of compaction of underground material. Groundwater withdrawal, which occurs due to excessive use of water resources, with drought and declining precipitation is among the most important reasons for this phenomenon. Therefore, land subsidence can lead to destructive results in residential, industrial and agricultural areas. Overlaying of subsurface sediments and collapses occurrence show that there is nearly good correlation between maximum water table depletion, loose sediments, clay thickness. Although the relationship between land subsidence, groundwater level decline and changes in the physical properties of subsurface material is broadly understood, a comprehensive and precise study to predict land subsidence remains unconstrained.

\section{References}

[1] M., Amighpey, S., Arabi, A., Talebi, Y., Djamour, Elevation change of the precise leveling tracks in the Iran leveling network, scientific report, National Cartographic Center (NCC) of Iran, Iran (2006).

[2] J. W.,Bell, F. Amelung, A. R. Ramelli, and G. Blewitt, Land subsidence in Las Vegas, Nevada, 1935- 2000: New geodetic data show evolution, revised spatial patterns, and reduced rates, Environ. Eng.Geosci., (2002), 8(3), pp. $155-174$ https://doi.org/10.2113/8.3.155.

[3] R., Burgmann, P. A. Rosen, and E. J. , Fielding Synthetic aperture radar interferometry to measure Earth's surface topography and its deformation, Annu. Rev. Earth Planet. Sci., (2000), 28, pp.169- 209.

https://doi.org/10.1146/annurev.earth.28.1.169

[4] E. Chaussard, S.Wdowinski, E.Cabral-Cano, F.Amelung, Land subsidence in central Mexico detected by ALOS InSAR time-series. Remote Sens. Environ. (2014), 140, pp.94-106. https://doi.org/10.1016/j.rse.2013.08.038

[5] T. H. Dixon, , F. Amelung, A. Ferretti, F. Novali, F. Rocca, R. Dokka, G. Sella,S.-W. Kim, S. Wdowinski, and D. Whitman, New Orleans subsidence: Space geodesy and Hurricane Katrina flooding, Nature, (2006), 441,pp. 578- 588. https://doi.org/10.1038/441587a

[6] Geological Survey of Iran (GSI), Geoelectric study in southwest plain of Tehran; (2008)5, 185p. (in Persian).

[7] Geological Survey of Iran (GSI), Geotechnical study in southwest plain of Tehran; (2008), 543 p. (in Persian).

[8] Geological Survey of Iran (GSI), Seismology study in southwest plain of Tehran; microtremor analysis with single station method,(2007) 2: 205p. (in Persian).

[9] Geological Survey of Iran (GSI), Land subsidence study in Tehran-Shahriyar plain, (2005)84 pp. ( in Persian).

[10] S. Ghorbanbeigi aid, J. Naji Hamodi, Land Subsidence in Tehran District, Iran - Sixth International Conference on Case Histories in Geotechnical Engineering (2008), http://scholarsmine.mst.edu /icchge/6icchge/ session06b/3.

[11]R.L.Hu, Z.Q. Yue, L.C. Wang, S.J.Wang, Review on current status and challenging issues of land subsidence in China, Engineering Geology, (2004)76: pp.65-77.

https://doi.org/10.1016/j.enggeo.2004.06.006 
[12] M.Mahmoudpour, M.Khamehchiyan, M.R.Nikudel, M.R.Ghassemi, Characterization of regional land subsidence induced by Ground water withdrawals in Tehran, Iran. JGeope (2013), 3 (2), PP. 49-62.

[13] J.P. Martínez, E.C. Cano, Sh. Wdowinski, M.H. Marín, J.Á.O. Lozano and M.E.Z. León, Application of InSAR and Gravimetry for Land Subsidence Hazard Zoning in Aguascalientes, Mexico,Remote Sens. (2015) 7, pp. 17035-17050; doi:10.3390/rs71215868. https://doi.org/10.3390/rs71215868

[14] M. Morseli, Land subsidence due to groundwater loss in the plains of Varamin. M.Sc. Dissertation. Shahid Beheshti University, Tehran (2008), (In Persian).

[15]Z. Mosavi, Study of land subsidence caused by underground water loss through the GPS and surveillance systems in plains of Iran. M.Sc. Dissertation, Tehran University, Iran (2003), (In Persian).

[16] M. Motagh, Y. Djamour, T.R.Walter, H.V. Wetzel, J. Zschau, and S. Arabi,. Land subsidence in Mashhad valley, Northeast of Iran, results from InSAR leveling and GPS, Journal of Geophysics, (2007), 168 , 2: pp. 518-528. https://doi.org/10.1111/j.1365-246X.2006.03246.x

[17] M. Motagh, Th.R. Walter, M.A. Sharifi, E. Fielding, A. Schenk, J. Anderssohn and J. Zschau, Land subsidence in Iran caused by widespread water reservoir Overexploitation, Geophysical Research Letters, (2008), V.35, L16403, doi:10.1029/2008GL033814,2008. https://doi.org/10.1029/2008GL033814

[18] S.M. Mousavi, A. Shamsai, M.H.Z. Naggar, M. Khamehchiyan, A GPS-based monitoring program of land subsidence due to groundwater withdrawal in Iran, Canadian Journal Civil Engineering, (2001),28,3, pp.452-462. https://doi.org/10.1139//01-013

[19]H. Motiee, E. Mcbean, A. Semsar, B. Gharabaghi, and V. Ghomashchi, Assessment of the contributions of traditional Qanats in sustainable water resources management, Int. J. Water Resour. Dev., (2006), 22,4, pp. 575-588. https://doi.org/10.1080/07900620600551304

[20] National Cartographic Center of Iran (NCC), Global Geodynamic Network of Iran, (2007), 16 pp., (in Persian).

[21]D. Ortiz-Zamora, A. Ortega-Guerrero, Evolution of long-term land subsidence near Mexico City: Review, field investigations, and predictive simulations. Water Resour. Res. (2010), 46, W01513. https://doi.org/10.1029/2008WR007398

[22]P. Peduzzi, H. Dao, C. Herold, F. Mouton, Assessing global exposure and vulnerability toward natural hazards: The Disaster Risk Index. Nat. Hazards Earth Syst. Sci. (2009), 9, pp.1149-1159. https://doi.org/10.5194/nhess-9-1149-2009

[23] M. Pishro, S. Khosravi, S.M. Tehrani, S.R. Mousavi, Modeling and zoning of land subsidence in the southwest of Tehran using artificial neural networks Int. J. Hum. Capital Urban Manage., (2016),1,3,pp.159-168.

[24] J. F. Poland, and G. H. Davis, Land subsidence due to withdrawal of fluids, in Reviews in Engineering Geology, Geol.Soc. of Am., Boulder, Colo., (1969), v.2, pp,187- 268.

[25] M. Sarraf, M. Owaygen, G. Ruta, and L. Croitoru, Islamic Republic of Iran: Cost assessment of environmental degradation, Tech. Rep. 32043-IR, World Bank, Washington, D. C. (2005).

[26]D. A. Schmidt, and R. Burgmann, Time-dependent land uplift and subsidence in the Santa Clara Valley, California, from a large interferometric synthetic aperture radar data set, J. Geophys. Res., (2003), 108 (B9), 2416. https://doi.org/10.1029/2002JB002267

[27] A. Shemshaki, M.J. Blourchi, F. Ansari,. Study of land subsidence in the plain of Tehran Shhriar. Engineering Geology, Environmental Management Group, GSI, Ministry of industries and mines. Engeo 84-06/02 Rep., (2005), Available at: www.gsi.ir/Images/Reports/subsidence.pdf (In Persian).

[28]P. Teatini, M. Ferronato, G. Gambolati, M. Gonella, Groundwater pumping and land subsidence in the Emilia Romagna coastland, Italy: Modeling the past occurrence and the future trend. Water Resour. Res., (2006), 42,1. https://doi.org/10.1029/2005WR004242

[29]Q. Wei, Land subsidence and water management in Shanghai. Delft University of Technology, Delft, The Netherlands, (2006).

[30]I.S. Zektser, E. Lorne, Groundwater resources of the world and their use. In IhP Series on groundwater (2004), (N.6).Unesco. 